Eskişehir Osmangazi Üniversitesi iißBF Dergisi

Ağustos 2020, C. 15, S. 2, $625-648$.

Başvuru : : 11.01.2019

Kabul : : 15.02.2020

\title{
Muhasebe Meslek Mensupları ile Mükelleflerin Beklentileri ve Sorunları: Nitel Bir Çalışma ${ }^{1}$
}

\author{
Aytül Bişgin² \\ Sema Ünlüer ${ }^{3}$ \\ M. Erkan Üyümez ${ }^{4}$
}

Muhasebe Meslek Mensupları ile Mükelleflerin Beklentileri ve Sorunları: Nitel Bir Çalışma

Öz

Muhasebe meslek mensuplarının ve mükelleflerin, birbirlerinden ve ilişki içinde oldukları kurumlardan hem maddi anlamda ve hem de yasal olarak birtakım beklentileri bulunmaktadır. Bu beklentiler aynı zamanda birtakım sorunların varlığına da dikkat çekmektedir. Bu araştırmada muhasebe meslek mensupları ile mükelleflerin beklentilerinin neler olduğu ve bu beklentilerin aynı zamanda hangi sorunları açığa çıkarttığı tespit edilmeye çalışılmıştır. Bu amaç çerçevesinde araştırma nitel araştırma yöntemiyle gerçekleştirilmiş ve durum çalışması olarak desenlenmiştir. Araştırma verileri 25 muhasebe meslek mensubu ve 15 vergi mükellefi ile yapılan yarı yapılandırılmış görüşmeler aracılığıyla toplanmıştır. Araştırma verilerinin analizi, tümevarım analizi yoluyla bilgisayar destekli nitel veri analizi programından biri olan NVivo 11 Pro yardımı ile gerçekleştirilmiştir. Araştırmanın bulguları ise araştırma sorusu temel alınarak sunulmuştur.

Anahtar Kelimeler: Muhasebe Meslek Mensupları, Vergi Mükellefleri, Nitel Araştırma Yöntemi, Beklentiler, Sorunlar.
Expectations and Problems of Accounting Professionals and Taxpayers: A Qualitative Study

\section{Abstract}

Accounting professionals and taxpayers have both financial and legal expectations from each other and from the institutions with which they are related. These expectations also draw attention to the existence of a number of problems. In this research, it is tried to determine what the expectations of the accounting professionals taxpayers are and what problems these expectations reveal at the same time. For this purpose, the search was carried out by qualitative research method and it was designed as a case study. The data were collected through semistructured interviews with 25 accounting professionals and 15 taxpayers. The analysis of the search data was carried out with the help of NVivo 11 Pro which is one of the computer aided qualitative data analysis program by induction analysis. The findings of the research are presented based on the research question.

Keywords: Accounting Professionals, Taxpayers, Qualitative Research Methodology, Expectations, Problems.

\section{Giriş}

Muhasebe mesleği, ülkelerin ekonomik yapısını oluşturan özel ve kamu işletmelerinin muhasebe ve denetim ile ilgili tüm ekonomik faaliyetlerini mevcut yasalara, ilkelere ve standartlara uygun olarak tarafsız, nesnel ve güvenilir bir biçimde gerçekleşmesini sağlayan bir meslek dalıdır (ỉbiş, 2002: 134). Ülkemizde muhasebe uygulamaları uzun yıllar, vergi muhasebeciliği

${ }^{1}$ Bu çalışma Anadolu Üniversitesi Sosyal Bilimler Enstitüsü Maliye Anabilim Dalı'nda Prof. Dr. M. Erkan Üyümez ve Dr. Öğr. Üyesi Sema Ünlüer danışmanlığında Aytül Bişgin tarafından “Türkiye'de Muhasebe Meslek Mensupları ile Mükellefler Arasında Gerçekleşen Etkileşimlerin Vergi Uyumu Bağlamında İncelenmesi” ismiyle tamamlanarak 10.08.2018 tarihinde savunulan doktora tezinden türetilmiştir.

${ }^{2}$ Arş. Gör. Dr., Karamanoğlu Mehmetbey Üniversitesi, iiBF, Maliye Bölümü, aytulbisgin@gmail.com, Yazar ORCID bilgisi: https://orcid.org/0000-0003-2488-3541

${ }^{3}$ Dr. Öğr. Üyesi, Anadolu Üniversitesi, Engelliler Entegre Yüksekokulu, Bilgisayar Kullanımı Bölümü, semaaktas@anadolu.edu.tr, Yazar ORCID bilgisi: https://orcid.org/0000-0003-2958-9798

${ }^{4}$ Prof. Dr., Anadolu Üniversitesi, IiBF, Maliye Bölümü, meuyumez@anadolu.edu.tr, Yazar ORCID bilgisi: https://orcid.org/0000-0001-7567-3486 
şeklinde gelişmiştir. Bu anlayış, meslek örgütlenmesine bağlı olarak muhasebe mesleğinin profesyonelleşmesine, sermaye piyasalarının gelişimine, işletmelerin kurumsallaşmasına ve işletme yönetimi anlayışındaki dönüşüme bağlı olarak değişiklik göstermiştir (Nalbantoğlu, 2003: 4). Muhasebe mesleği, ekonominin gelişmesi ve şirket yapılarının daha karmaşık hale gelmesi, mevzuatta yaşanan hızlı değişimler, meslek mensubu sayısında yaşanan hızlı artış ve haksız rekabet gibi birçok faktör dolayısıyla gün geçtikçe daha stresli ve yorucu bir meslek haline gelmiştir. Günümüzde ise muhasebe meslek mensuplarının yaptıkları işler defter tutmanın ötesine geçmiş daha çok danışmanlık hizmeti haline gelmiştir (Aydemir, 2015: 71-84).

Muhasebe meslek mensupları için en önemli gelişme ise, 3568 sayılı Serbest Muhasebeci Mali Müşavirlik ve Yeminli Mali Müşavirlik Kanunu'nun yürürlüğe girmesiyle yaşanmıştır. Muhasebe mesleği 1989 yılında yürürlüğe giren bu 3568 sayılı Kanun ile yasal bir zemine oturtulmuştur. 2008 yılında yapılan değişiklik ile ise ilgili yasada Serbest Muhasebecilik unvanı çıkartılmıştır. Serbest Muhasebeci Mali Müşavirlik ve Yeminli Mali Müşavirlik unvanları ise güncel olarak geçerliğini korumaktadır.

Tüm bu gelişmelerin yanı sıra toplumun refahı ve kalkınması açısından önemli yerleri olan muhasebe mesleğini icra edenlere yani muhasebe meslek mensuplarına vergi uyumunun sağlanması açısından da birtakım görevler düşmektedir. Bu görevlerin yerine getirilmesi aşamasında hem muhasebe meslek mensuplarının hem de sürekli etkileşim halinde oldukları mükelleflerin beklentileri önem arz etmektedir. Bu araştırmada "Muhasebe meslek mensupları ve mükelleflerin beklentileri nelerdir? Gerçekleşenler nelerdir?" sorusundan hareketle, muhasebe meslek mensupları ile mükelleflerin birbirlerinden, ilişki içinde oldukları kurumlardan ve yasal açıdan ne tür beklentilerinin olduğu ve bu beklentilerin hangi tür sorunları açığa çıkarttığı tespit edilmeye çalışılmıştır.

$\mathrm{Bu}$ araştırmada öncelikle kavramsal çerçeve açıklanmış ve sonrasında muhasebe meslek mensuplarının ve mükelleflerin beklentileri ve sorunları üzerine yapılan çalışmalara yer verilmiştir. Ardından yöntem kısmına geçilmiş, araştırmanın modeli, araştırmanın katılımcıları ve özellikleri, veri toplama teknikleri ve süreci, verilerin analizi ile araştırma etiğinden bahsedildikten sonra yapılan derinlemesine yarı yapılandırılmış görüşmelerden elde edilen bulgular alıntı yapılarak sunulmuş ve yorumlanmıştır.

\section{Literatür}

Muhasebe meslek mensuplarının ve mükelleflerin beklentilerine ve sorunlarına ilişkin literatürde birçok çalışma yer almaktadır. Bu çalışmaların daha çok nicel çalışmalar olduğu göze çarpmaktadır. Bu çalışma ise nitel yöntem kullanılarak gerçekleştirildiği için özgün bir çalışma olarak literatürde yerini alacaktır. Bu başlık altında yapılan çalışmaların bir kısmına yer verilecektir.

Suadiye ve Yükselen (2001) tarafından yapılan çalışmada mükelleflerin ve muhasebecilerin birbirlerinden beklentilerine yönelik olarak Hatay ilinde bir araştırma yapılmıştır. Araştırmada Antakya Ticaret ve Sanayi Odası ile Esnaf ve Sanatkâr Odaları Birliği'ne üye 261 mükellefe ve 210 muhasebe meslek mensubuna (SMMM, SM) ulaşılabilmiş ve veriler anket yoluyla elde edilmiştir. Araştırmanın bulguları ise, mükelleflerin muhasebecilerden daha çok vergisel işlemler aldıklarını ve memnun olduklarını, mükelleflerin muhasebecilerden bilgi alma ihtiyacı duydukları konuların ise mevzuattaki değişiklikler, yeni iş yeri açma, iş yapma hakkında bilgi alma, büyüme olanaklarını araştırma gibi konular olduğu şeklindedir. Diğer taraftan muhasebecilerin 
mükelleflerden beklentileri ise daha çok muhasebe ücretini düzenli olarak ödeme, belgelerini zamanında verme, belgeleri ve ödemeleri son güne bırakmama şeklinde olduğu belirtilmiştir.

Kalaycı ve Tekşen (2006) tarafından yapılan çalışmada Isparta il merkezinde 52 muhasebe meslek mensubuna (SM, SMMM, YMM) yüz yüze görüşme suretiyle uygulanan bir anketle, muhasebecilerin beklentilerinin neler olduğu tespit edilmiştir. Muhasebecilerin mükelleflerden beklentileri; mükelleflerin muhasebe ücretlerini aylık olarak ödemeleri, muhasebe belgelerini zamanında eksiksiz olarak getirmeleri, vergi ödemelerini kendilerinin yapmaları, finansal konularda muhasebecilerle sürekli bağlantılı olmaları, sorumluluklarının farkında olmaları ve sahte belge düzenlememeleri ve kullanmamaları olarak belirtilmiştir. Muhasebecilerin Odalardan beklentileri; aylık dergi çıkartılması, meslektaşlar arasındaki haksız rekabete çözüm bulunması, gezi ve sosyal aktivitelerin artırılması, kanunlarla ilgili değişikliklerin en kısa sürede bildirilmesi, resmi kurumlarla ilgili karşılaşılan sorunların çözümüne yardımcı olunması ve meslek içi eğitimlerinin artırılması olarak sayılırken, TÜRMOB'dan beklentileri ise; vergi sisteminin daha düzenli hale getirilmesi ve vergi dairelerinin biraz daha aktif çalışması için Maliye Bakanlığı ile iletişim kurulması, muhasebecilerin sorumluluklarının ve iş yüklerinin azaltılması için ilgili kurumlarla istişare edilmesi ve vergi yargısının daha hızlı karar vermesinin sağlanması olarak sayılmıştır. Çalışmada muhasebecilerin karşılaştıkları sorunlar ise: Mükellefler tarafından en iyi muhasebecinin en az vergi ödeten muhasebeci olarak görünmesi, meslek mensuplarının genellikle her gün kanunlarda yapılan değişiklikleri takip edememesi, ankete katılan meslek mensuplarının büyük bir çoğunluğunun meslektaşları tarafından ucuz defter tutulduğunu belirtmesi ve muhasebecilik mesleğinde iş yükünün çok fazla olması olarak belirtilmiştir.

Tuğay ve Tekşen (2014) tarafından Burdur ilinde yapılan çalışmada bağımsız olarak çalışan muhasebe meslek mensuplarına anket uygulanmıştır. Çalışmada muhasebe meslek mensuplarının mükelleflerden beklentileri, mükelleflerin belgeleri zamanında teslim etmesi ve vergi ödemelerini mükelleflerin kendilerinin yapması gerektiği belirtilmiştir. Muhasebe meslek mensuplarının sorunları ise, muhasebeciden az vergi ödetmesinin istenmesi, mevzuat değişikliklerinin çok sık olması, haksız rekabetin olması, yoğun iş yükü ve ücretlerin tahsilinde yaşanan sıkıntılar olarak belirtilmiştir.

Deran ve Beller (2017) tarafından yapılan çalışmada ise Niğde ilinde faaliyet gösteren muhasebe meslek mensuplarının bağlı oldukları meslek odasından beklentileri, Sosyal Güvenlik Kurumu ile meslek mensupları arasında oluşan sorunların çözümüne yardımcı olmaları, mükelleflerden tahsil edilen ücretin tüm meslek mensupları arasında standart bir şekilde uygulanması, denetlenmesi ve tahsili konusunda yaptırım gücü yüksek düzenlemelerin getirilmesi olarak belirtilmiştir. Çalışmada ayrıca mevzuatın sık sık değişimi ile ilgili sorunlar, Tek Düzen Muhasebe Sistemi'nin uygulanması ile ilgili sorunlar, mükelleflerin muhasebe mesleğine yeteri kadar önem vermemeleri, mükelleflerin zamanında ve yeterli bilgi vermemeleri, mükelleflerden tahsil edilen ücretler ile ilgili sorunlar, mükelleflerin kanun dışı davranışlarda bulunma önerileri gibi sorunlar tespit edilmiştir. 


\section{Yöntem}

Bu kısmında araştırmanın modeli, araştırmanın katılımcıları ve özellikleri, veri toplama teknikleri ve süreci, verilerin analizi ile araştırma etiği yer almaktadır.

\subsection{Araştırmanın Modeli}

Bu araştırmada, muhasebe meslek mensupları ile mükelleflerin beklentilerinin neler olduğu ve bu beklentilerin hangi sorunları ortaya çıkaracağı amaçlandığından, araştırma nitel araştırma yöntemiyle gerçekleştirilmiş ve durum çalışması (case study) olarak desenlenmiştir.

Nitel araştırma, gözlem, görüşme ve doküman analizi gibi nitel veri toplama tekniklerinin kullanıldığı, algıların ve olayların doğal ortamda gerçekçi ve bütüncül bir biçimde ortaya konmasına yönelik nitel bir sürecin izlendiği araştırma olarak tanımlanabilir (Yıldırım ve Şimşek, 2013: 45). Nitel araştırmada yer alan desenler ise: "kültür analizi", "olgubilim", "kuram oluşturma", "durum çalışması" ve "eylem araştırması"dır (Yıldırım ve Şimşek, 2013: 76-84).

Durum çalışması, araştırmacının sınırları belli bir sistemi, belli bir zaman dilimi içerisinde farklı kaynaklar kullanarak (gözlemler, görüşmeler, işitsel görsel materyaller, belgeler ve raporlar) detaylı bir şekilde betimlemesi ve bu duruma dayalı temaları ortaya koyması olarak tanımlanmıştır (Creswell, 2007: 72). Bir başka tanımda ise durum çalışması, yoğun ve bütüncül bir betimleme olarak ve tek bir olayın, olgunun ya da toplumsal bir birimin analizi olarak belirtilmiştir (Merriam, 1998: 27).

Araştırmada izlenen aşamalar ilgili literatürün taranması ile başlayıp yarı yapılandırılmış görüşme formlarının hazırlanması, yarı yapılandırılmış görüşme formlarının uygulanması, verilerin analiz edilmesi, bulguların raporlaştırılması ve yorumlar ile sonuç kısmından oluşmaktadır. İzlenen bu aşamalar bir döngü şeklindedir ve sürekli olarak geçerlik ve güvenirlik çalışmaları yapılmıştır.

\subsection{Araştırmanın Katılımcıları ve Özellikleri}

Araştırmanın katılımcıları, amaçlı örnekleme yöntemlerinden biri olan "kartopu örneklem" ile seçilmiştir. Kartopu örnekleme, araştırmacının problemine ilişkin olarak zengin bilgi kaynağı olabilecek birey veya durumların saptanmasında özellikle etkilidir. Süreç çok basit bir soruyla başlar: "Bu konuda en çok bilgi sahibi kimler olabilir? Bu konuyla ilgili olarak kim veya kimlerle görüşmemi önerirsiniz?" (Patton, 1987: 56). Süreç ilerledikçe elde edilen isimler veya durumlar tıpkı bir kartopu gibi büyüyerek devam edecek, belirli bir süre sonra belirli isimler hep öne çıkmaya başlayacak, araştırmacının görüşmesi gereken birey sayısı veya ilgilenmesi gereken durum sayısı azalmaya başlayacaktır (Yıldırım ve Şimşek, 2013: 139).

Kartopu örnekleme yöntemiyle seçilen iki katılımcı grubunu muhasebe meslek mensupları ve vergi mükellefleri oluşturmaktadır. Görüşme yapılacak muhasebe meslek mensuplarının seçiminde alanında deneyimli olmasına, vergi mükelleflerinin seçiminde ise işinde uzun yıllar faaliyet göstermiş olmasına özen gösterilmiştir.

Araştırmanın katılımcı grubundan biri olan 25 muhasebe meslek mensubundan, $18^{\prime}$ i serbest muhasebeci mali müşavirler iken 7'si ise yeminli mali müşavirlerden oluşmaktadır. Muhasebe meslek mensuplarının mesleki deneyimleri 3 ile 39 yıl arasında değişmektedir. 15 vergi mükellefinden oluşan bir diğer katılımcı grubu ise gelir vergisi mükellefleri ile kurumlar vergisi mükellefiyeti ile ilgisi bulunan mükelleflerden oluşmaktadır. Görüşme yapılan vergi mükellef- 
lerinden $5^{\prime} i^{5}$ büyük ölçekli işletme sahibi iken, kalan $10^{\prime} u^{6}$ ise küçük ve orta ölçekli işletme sahibidir. Araştırmada veri çeşitliliğini artırmak için farklı sektörlerde (inşaat, otomasyon, bilişim, tarım, giyim sanayi vb.) faaliyet gösteren tecrübeli vergi mükellefleri ile görüşülmüştür. Mükelleflerin iş deneyimleri ise 2 ile 64 yıl arasında değişmektedir.

\subsection{Veri Toplama Teknikleri ve Süreci}

Bu araştırmada verilerin toplanmasında "görüşme" tekniği kullanılarak, derinlemesine yarı yapılandırılmış görüşmeler gerçekleştirilmiştir. Hem muhasebe meslek mensupları ile hem de mükellefler ile yapılan derinlemesine yarı yapılandırılmış görüşmeler yüz yüze, ses kayıt cihazı kullanılarak gerçekleştirilmiştir. Görüşme sorularının hazırlanması, uygulanması ve raporlaştırılması aşamalarının her birinde belirli aralıklarla, alan uzmanı, nitel araştırma uzmanı ve araştırmacının yer aldığı geçerlik komitelerinde, geçerlik ve güvenirlik çalışmaları yapılmıştır. Görüşmeler Eskişehir, Ankara ve İstanbul olmak üzere üç ilde gerçekleştirilmiştir. Veri toplama süreci ise 02.12.2017-05.08.2017 tarihleri arasını kapsamaktadır.

\subsection{Verilerin Analizi}

$\mathrm{Bu}$ araştırmada elde edilen veriler, nitel veri analizi yöntemlerinden tümevarım analizi yoluyla çözümlenmiştir. Tümevarım analizinde temel amaç, toplanan verileri açıklayabilecek kavramlara ve ilişkilere ulaşmaktır. Tümevarım analizinde birbirine benzeyen veriler belirli kavramlar ve temalar çerçevesinde bir araya getirilir ve bu veriler okuyucunun anlayabileceği bir şekilde düzenlenerek yorumlanmaktadır. Analiz süreci ise verilerin kodlanması, temaların bulunması, kodların ve temaların düzenlenmesi ile bulguların tanımlanması ve yorumlanması şeklindedir (Yıldırım ve Şimşek, 2013: 259-260). Araştırma verilerinin analizi bilgisayar destekli nitel veri analizi programından biri olan NVivo 11 Pro yardımı ile gerçekleştirilmiştir.

\subsection{Araştırma Etiği}

Araştırmanın başlangııından itibaren tüm verilerin geçerli bir şekilde toplanmasına özen gösterilmiştir. Gerçekleştirilen yarı yapılandırılmış görüşmeler ses kayıt cihazı ile kayıt altına alınmıştır. Yarı yapılandırıımış görüşmelerin öncesinde tüm katılımcılardan yazııı izin alınmıştır. Ayrıca araştırmaya dâhil olan katılımcıların isimleri kesinlikle deşifre edilmemiş, görüşme verilerinin analizinde katılımcı isimleri yerine SMMM (1), YMM (7) ve Mükellef (5) gibi kod isimler kullanılmıştır.

\subsection{Bulgular ve Yorumlar}

Araştırmanın bu kısmında $25^{\prime} \mathrm{i}$ muhasebe meslek mensubu $15^{\prime} \mathrm{i}$ ise vergi mükellefi olmak üzere toplamda 40 katılımcıdan toplanan verilerden elde edilen bulgular yer almaktadır. Bu bulgular "Muhasebe meslek mensupları ile mükelleflerin beklentileri nelerdir? Gerçekleşenler nelerdir?" şeklindeki araştırma sorusu çerçevesinde hem muhasebe meslek mensuplarından hem de vergi mükelleflerinden elde edilen verilerden alıntı ${ }^{7}$ yapılarak sunulmuş ve yorumlanmıştır.

\footnotetext{
${ }^{5}$ Mükellef (6), Mükellef (7), Mükellef (8), Mükellef (9), Mükellef (11).

${ }^{6}$ Mükellef (1), Mükellef (2), Mükellef (3), Mükellef (4), Mükellef (5), Mükellef (10), Mükellef (12), Mükellef (13), Mükellef (14), Mükellef (15).

${ }^{7}$ Alıntı yapılarak sunulan görüşme verilerinin sonunda yer alan tarihler, görüşmenin yapıldığı tarihi belirtmektedir.
} 


\subsubsection{Muhasebe Meslek Mensuplarının Beklentileri}

Muhasebe meslek mensupları ile yapılan derinlemesine yarı yapılandırılmış görüşmelerden elde edilen verilerden "Beklentiler" adlı ana tema ve bu ana temayla ilişkili alt temalara ulaşılmıştır. Bu alt temalar ise "Mükelleflerden", "Mesleki kuruluşlardan" ve "Yasa koyucudan 3568 sayılı Kanun bağlamında" olmak üzere üç alt temadan meydana gelmektedir. Ayrıca "Mükelleflerden" adlı alt tema yine "Yasal yükümlülükler açısından" ve "Maddi açıdan" olmak üzere ikiye ayrılmıştır. İlgili temaların frekans dağıımı ${ }^{8}$ aşağıdaki şekil yardımıyla açıklanmıştır.

Şekil 3.1. "Beklentiler" Adlı Ana Tema ve Alt Temalar

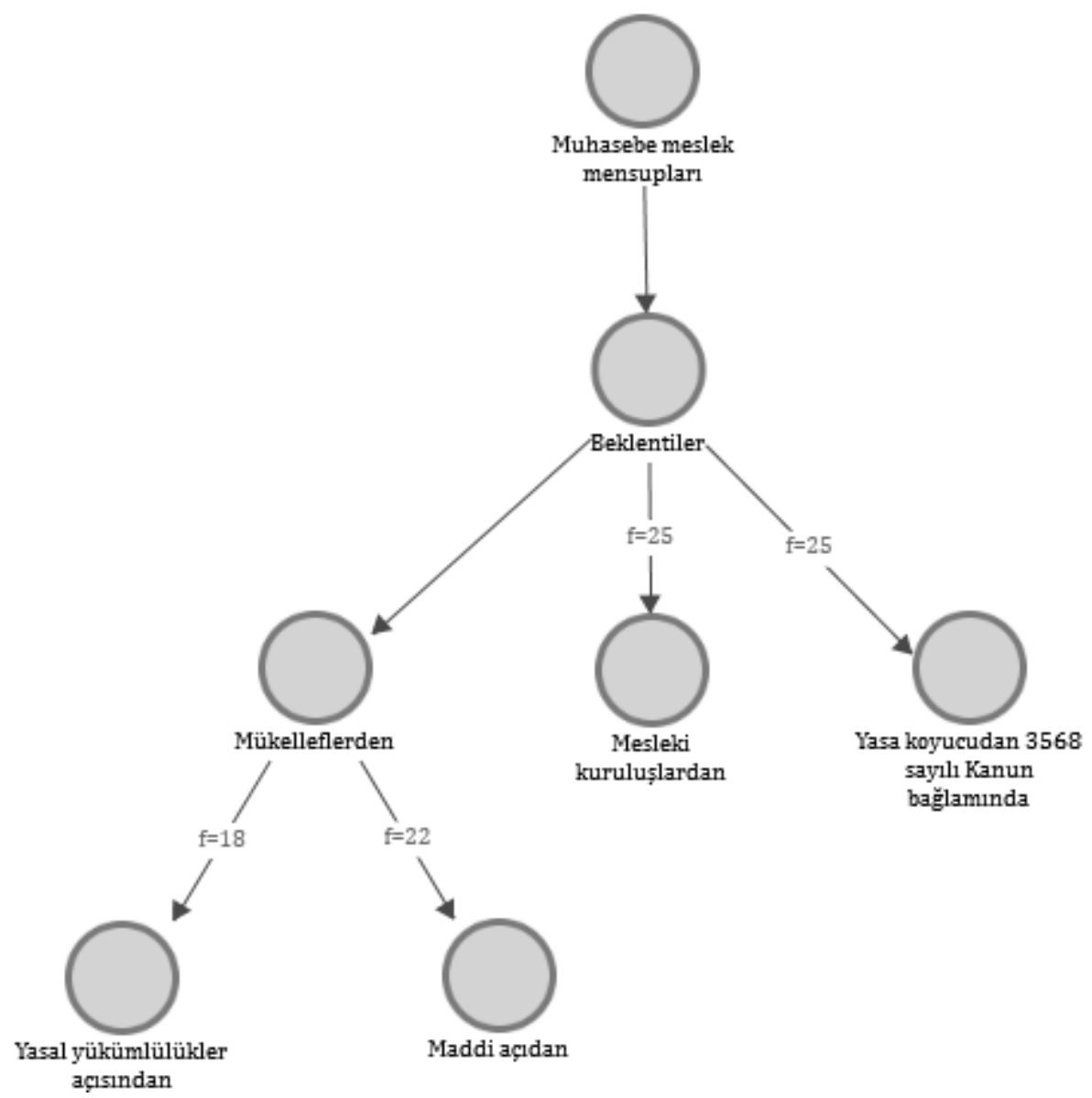

${ }^{8}$ Frekans dağılımı, muhasebe meslek mensuplarının görüşlerinin sayısını ifade etmektedir. 


\subsubsection{Mükelleflerden Beklentiler}

Kendileriyle görüşme yapılan muhasebe meslek mensupları, mükelleflerden hem yasal yükümlülükler açısından hem de maddi açıdan beklentilerine dair görüş bildirmiştir.

\subsection{Yasal Yükümlülükler Açısından Beklentiler}

Muhasebe meslek mensuplarından $18^{\prime} i^{9}$ mükelleflerden yasal yükümlülükler açısından beklentisini dile getirmiştir. SMMM (6), yasal yükümlülükler açısından mükelleften beklentisini müteselsil sorumlulukları bağlamında değerlendirerek şu şekilde ifade etmiştir:

SMMM (6): Yasal yükümlülükler açısından tabii müteselsil sorumluyuz, vermiş olduğumuz beyannameler ve tutmuş olduğumuz defterler açısından bizi zor duruma sokmayacak şekilde abuk sabuk faturaları, şunları, bunları, sokmazlarsa evrakların içerisine ki, biz hepsini bilmek zorunda değiliz, bilemeyiz, evrak takip edemeyiz, tek tek bu fatura gerçek mi değil mi diye. Ama mükellef de artık bu kadar bu işin kurnazı olmuş insanlar var ki, kendisi ne kadar vergi çıkacağı, ne kadar KDV çıkacağını önceden görerekten piyasadan fatura alıyorlar. Ve müteselsil olarak da biz bu konuda sorumluyuz. (...) (08.05.2017)

Katılımcının yukarıda belirtmiş olduğu görüşten müteselsilen sorumlu oldukları için mükelleflerden yasal düzenlemelere uyulmasını beklediği anlaşılmaktadır. Ancak, örneğin belge düzeninin gerçeği yansıtıp yansıtmadığını takip edemediklerini, mükelleflerin kendi vergi yüklerini kendilerinin tespit ederek bunu azaltmak için belge temin edebildiklerini belirtmektedir. Aynı şekilde mükelleften belge düzenine uyması gerektiğini ancak mükelleflerin bu konuda hassas davranmadıklarını belirten SMMM (10)'un “...Belge düzeni veya işte böyle en azından bize sormadan kafalarına göre abuk sabuk bir şey yapmamaları. Çünkü bazen öyle durumlarla karşılaşıyoruz yani bir tane firma işte o ay yüklü bir iş yapmış, bir baktım bir fatura geldi önüme, bir balya fatura geldi. Yani faturayı kesmiş bu, bir kamu kurumuna kesmiş bir balya fatura geldi önüme. Ne bu, ağabey işte biz de bunları aldık, tabii bana da diyemiyor ama çok anlaşılır artık 20 senedir işin içinde olduğumdan naylon fatura olduğu..." şeklindeki görüşü ile SMMM (11)' in "...Tabii naylon fatura veya düşük vergi ödeme taleplerinin olmaması en büyük beklentimiz..." şeklindeki görüşü, SMMM (6)'nın yukarıdaki görüşünü destekler nitelikteki bulgulardir.

SMMM (7) ise, yasal yükümlülükleri açısından mükelleflere telkinde bulunduklarını ancak mevcut vergi sisteminde olan vergi affı gibi birtakım sıkıntılardan ötürü mükelleflerin kendilerini ciddiye almadıklarını şu şekilde ifade etmiştir:

SMMM (7): (...) Yani bizim yasal yükümlülükler açısından mükellef dediğim gibi vergi affının bu kadar çok çıktığı bir ülkede doğal olarak biz de ciddiyetimizi kaybediyoruz. Yani bize karşı mükelleflerin aman vergini öde sonra sıkıntı yaşarsın gibi cümlelerimizi havada görmeye başlıyor. (...) (08.05.2017)

Diğer taraftan YMM (23) ise mükelleflerin yeterince bilinçli olmadıklarını ve tam anlamıyla yasal yükümlülüklere uyulması halinde firmalar zora düşebileceğinden mükelleflerin vergi yüklerini azaltmak bakımından da muhasebe meslek mensuplarının bir faaliyet gösterdiklerini, ancak mükelleflerin bunun farkında olmayışını ima etmiş ve ayrıca mükellef profilinin geleceğe dair planlamadan ziyade anlık çıkabilecek sorunları çözmeye odaklandığını belirterek düşüncesini şu sözlerle ifade etmiştir:

${ }_{9}^{9} \mathrm{SMMM}(1), \operatorname{SMMM}(2), \mathrm{YMM}(4), \operatorname{SMMM}(6), \operatorname{SMMM}(7), \operatorname{SMMM}(9), \operatorname{SMMM}(10), \operatorname{SMMM}(11), \operatorname{SMMM}(12), \operatorname{SMMM}$ (13), SMMM (17), SMMM (18), SMMM (19), YMM (21), YMM (22), YMM (23), SMMM (24), YMM (25). 
YMM (23): (...) Mükellefin bakış açısının da anı çözmek yerine geleceği planlayarak hareket etmesi. Bizim ülkemizde maalesef bu düzeyi yakalamak öyle kolay değil. Ben masanın öbür tarafında yer almış ve denetim yapmış biri olarak söylüyorum para kazandığımda her şeyin güllük gülistan olduğunu bu odaklı çalışıldığında gelecekte birçok firmanın batabileceğini, battığını da gördüğümü bildiğim için biraz düzeyleri bu anlamda biraz şey mükelleflerin. $O$ düzeye ulaşabilmeleri gerekiyor ama biraz ya bizden kaynaklı mı diyeyim ya da bizim rekabet koşullarımızın mesleğe getirdiği nokta mı diyeyim bu anlamda mükelleflerin yani verilen hizmetin çok değerini bilmediğini düşünüyorum ben. (...) (20.06.2017)

Yukarıda alıntı yapılarak verilen YMM (23)'ün “...Mükelleflerin yani verilen hizmetin çok değerini bilmediğini düşünüyorum...” şeklindeki görüşü ile SMMM (8)'in “...Bazıları gelip diyor ki ağabey bir tane kâğıt parçası çıkarttın aylarca uğraşıp ya da beyanname verdin diye basite indirgeyebiliyorlar. Aslında arka tarafta dünya iş dönüyor..." şeklindeki görüşü birbirini destekler nitelikteki bulgulardır.

Elde edilen bulgulardan muhasebe meslek mensuplarının mükelleflerden yasal yükümlülükler açısından beklentilerinin;

- Gerekli olan evrakların her ay düzenli olarak kendilerine iletilmesi,

- Belge düzeni konusunda yaptıkları uyarıların mükellefler tarafından dikkate alınması,

- Mükelleflerin ileride çıkabilecek sorunları en aza indirgemeleri açısından planlama yaparak hareket etmeleri,

- Belge düzeni konusunda vergi kanunları çerçevesinde hareket etmeleri ve özellikle sahte fatura temin etmemeleri ya da böyle bir talepte bulunmamaları aksi takdirde muhasebe meslek mensuplarına da sorumluluk yüklenebileceğinin bilincinde olarak hareket etmeleri ve

- Ayrıca yaptıkları iş ve işlemlerin mükelleflerce saygı gösterilmesi ve mesleklerinin küçümsenmemesi gerektiği şeklinde olduğu tespit edilmiştir.

Sonuç olarak muhasebe meslek mensuplarının vergi mükelleflerinden yasal yükümlülükler açısından birçok beklentisi bulunmaktadır. Bu yasal yükümlülüklerinin yerine getirildiği yönünde görüş bildiren muhasebe meslek mensupları olduğu gibi, mükelleflerin bilinçsiz olduğu, dolayısıyla görev ve sorumluluklarının bilincinde hareket etmedikleri yönünde görüş bildiren muhasebe meslek mensupları da bulunmaktadır. Söz konusu yasal yükümlülüklere uyulması hem muhasebe meslek mensuplarının iş ve işlemlerini doğru ve zamanında yapabilmeleri açısından hem de mükelleflerin devletle karşı karşıya kalmaması ve herhangi bir ceza almamaları açısından önem taşımaktadır.

\subsection{Maddi Açıdan Beklentiler}

Muhasebe meslek mensuplarından $22^{\prime} \mathrm{si}^{10}$ mükelleflerden verdikleri hizmetin karşılı̆̆ı olan bedeli zamanında ödemeleri konusundaki beklentilerini dile getirmiştir.

YMM (23)'ün "...Ben kaliteli iş verip ve bunun da bedelini alabilmeyi planlıyorum..." şeklindeki görüşü, SMMM (6)'nın “...Aldığı hizmetin karşılığını zamanında versin...” şeklindeki görü-

${ }^{10}$ SMMM (1), YMM (3), YMM (4), SMMM (5), SMMM (6), SMMM (8), SMMM (9), SMMM (10), SMMM (11), SMMM (12), SMMM (13), SMMM (14), SMMM (15), SMMM (16), SMMM (17), SMMM (18), SMMM (19), YMM (20), YMM (21), YMM (22), YMM (23), YMM (25). 
şü, SMMM (10)'un “...Gününde paralarını ödemeleri...” şeklindeki görüşü, SMMM (11)'in "...Zamanında ücretini ödemesi bütün mali müşavirlerin en büyük beklentisi..." şeklindeki görüşü, SMMM (12)'in "...Aylık düzenli ödemelerimizi yapsalar bizim başka bir beklentimiz yok..." şeklindeki görüşü ile SMMM (15)'in “...Emek ve zamanımızın karşılığını almak ve paramızı tabii ki zamanında almak. Bizim en büyük beklentimiz bu..." şeklindeki görüşü birbirlerini destekler nitelikteki bulgulardır.

SMMM (14) kodlu katılımcı ise bu konudaki görüşünü ifade ederken öncelikli beklentisinin işine duyulan saygı olması gerektiğini, çünkü mükelleflerin muhasebe meslek mensubunca verilen hizmetin çok bilincinde olarak hareket etmediklerini dolayısıyla yapacakları ödemeleri ertelemelerinin direkt olarak kendi performanslarını olumsuz etkilediğini şu şekilde ifade etmiştir:

SMMM (14): (...) Öncelikle beklentim yaptığım işe saygı duyulması. Yani bir ortaklık anlayışı içerisinde yürümek gayretinin olmasını bekliyorum. Sonuçta bu işletme para kazanırsa ben de para kazanabilirim. Bu işletme bir maliyetle bir kazanırken az kazanabilirim bir maliyetle 5 kazanırsa daha fazla talep edebilirim. Pasta ne kadar büyükse benim isteyeceğim pay da o kadar büyük olabilir. Pasta ne kadar küçükse benim isteyeceğim pay da o kadar azalacaktır. Mükelleflerimde özellikle bu vurguyu çok yapıyorum yani ben sizin ortağınızım. Benden saklamanız gereken bir şey yok. Ben de ne kadar işinizin mali boyutuna yani ben gidip de işte bir kimya fabrikasına şu ürünün şeyini reçetesini formülünü istemiyorum. Ama bu ürünün üretilmesi için yapılan harcamalar, masraflar, maliyetler satışlar kullanılan personel, personel nitelikleri, yeterlikleri gibi ne kadar çok mali veriyi benimle paylaşırlarsa üreteceğim çözüm sunacağım farklı alternatiflerin daha fazla artacağını bilmelerini yaptığım bu işe saygı göstermelerini benim de hayatımı idame ettirebilmem için bir ücret ödemelerinin gerekli olduğunu ham maddeciye yapmaları gereken ödemeyi ötelemeyecekleri gibi bana yapmaları gereken ödemeyi ötelemelerinin de sonuçlarının benim iş performansıma direk olarak yansıyacağını, benim çalışırken kafamda bugün akşam telefon faturası var ödeyebilecek miyiz acaba sorusu varken benim o işi verimli olarak yapamayacağımı bilmeleri. (...) (31.05.2017)

Bir diğer dikkat çekici bulgu ise SMMM (8)'in mükelleften beklentisini mükellefin kendisinden ne beklediğiyle alakalı olduğu yönündeki düşüncesidir. Yani mükellef ne talep ederse meslek mensubunun o yönde beklentisini oluşturduğunu ve dolayısıyla mükellef profiline göre verdiği hizmetin bedelini de almak istediğini katılımcı şu şekilde dile getirmiştir:

SMMM (8): (...) Mükellefin ne beklediğiyle alakalı. Yani mükellef benden sadece beyanname istiyorsa ben bunu yapıyorum. Ama bilinçli mükellefler için daha farklı hizmetler yapıyorsunuz tabii ki onun karşılığını almak istiyorsunuz. Ben sadece beyanname meslek mensubu değilim aslında ben böyle yeteneklerim de var bunun da karşılı̆ını görebileceğim müşteriler edinmek istiyorum, onlar da bu karşıllğı versinler istiyorum aslında beklentilerim onlar. (...) (08.05.2017)

Elde edilen bulgulardan muhasebe meslek mensuplarının mükelleflerden maddi anlamda beklentilerinin:

- Verdikleri hizmetin karşılığı olarak sözleşmede belirtilen tutarın kendilerine zamanında ödenmesi ve

- Emek ve zamanlarının karşılığı olan tutarı almak istedikleri şeklinde olduğu tespit edilmiştir. 
Sonuç olarak mükelleflerden en öncelikli beklentisinin maddi anlamda olduğu yönünde görüş bildiren muhasebe meslek mensupları vardır. Bu beklentiyi ise yaptıkları işte harcadıkları zaman ve verdikleri emek ile ilişkilendiren muhasebe meslek mensupları bulunmaktadır. Dolayısıyla muhasebe meslek mensupları verdikleri hizmetin karşılığını zamanında ve tam olarak almak istemektedirler.

\subsubsection{Mesleki Kuruluşlardan Beklentiler}

Kendileriyle görüşme yapılan muhasebe meslek mensuplarının hepsi mesleki kuruluşlardan özellikle meslek odalarından beklentilerine ilişkin görüş bildirmiştir.

SMMM (1), Odalar tarafından muhasebe meslek mensuplarına özellikle mevzuat, haksız rekabet ve etik konularında eğitim verilmesi gerektiğini belirtmiş ve verilen eğitimlerin zamanlaması açısından sıkıntıyı dile getirmiştir. Ayrıca Odaların denetim mekanizması çalışmadığından paravan danışmanlık şirketlerinin piyasada faaliyet gösterdiklerini şu şekilde ifade etmiştir:

SMMM (1): (...) Odalardan beklentimiz, biz mali müşavirler olarak aramızda bir birlik yok. Her şeyden önemlisi birliğin sağlanması gerekiyor. İkincisi ve en önemlisi sürekli eğitim, sürekli eğitim. (...)

(...) 40 yılın başında bir eğitim planlaması yapıyorlar o da beyanname verme gününde. Şimdi ben buna nasıl güvenirim. Yani sırf yapmış olmak için eğitim yapılamaz ve sadece mevzuat açısından değil, haksız rekabet konusunda olsun, bu konularda mesleğin etik kuralları konusunda olsun kesinlikle üyelerini bilgilendirmesi gerekiyor ki birtakım sıkıntılar doğma$\sin$ (...)

(...) Bizim Odamızın mesela denetim mekanizması var mali müşavir olmayan bir kişi mali müşavirlik hizmeti veremez. Ama şu anda ben biliyorum ki 400 tane şirkete danışmanlık veren ve mali müşavir olmayan yerler var. (...) (02.12.2016)

SMMM (1)'in Odaların denetim mekanizmasının işlemediği yönünde yukarıda yer alan görüşü, SMMM (14)'ün “...TÜRMOB ya da Odalar sonuçta bizlerin oluşturduğu birbirimize karşı hak yükümlülük ve sorumluluklarımızı birtakım kurallar altına aldığımız yerler. Bu böyle mi olmalı, bence hani bu Odaların görevleri sadece bunların işleyip işlemediğini denetlemek olmaIı. Meslek mensuplarının bunları kendilerinin içselleştirip ortaya koyması gerekirken bunun yapılmıyor olması nedeniyle Odaların ve TÜRMOB'un bu konuda aktif rol almasını bekliyoruz. Bu da birtakım kaygılar nedeniyle olmuyor... Işste etik kurallarımız var. Etik kurallarımıza uyuluyor mu uyulmuyor. Yüzde 90 ben uyulduğuna rastlamadım..." şeklindeki görüşü ile SMMM (18)' in "...Odanın daha çok rekabet olmaması için muhasebe bürolarını denetlemeleri gerekiyor..." şeklindeki görüşü birbirlerini destekler nitelikteki bulgulardır.

Yine SMMM (1)'in Odalar tarafından verilen eğitimlerin zamanlama açısından sıkıntılarının olduğu yönünde olan yukarıdaki görüşü ile SMMM (14)'ün “...Bizim yoğun çalışma dönemlerimiz belli. Işste periyodik vergi takvimimiz var. Işste nedir 23'ü muhtasardır, sigorta bildirimleridir. 24'ü KDV'dir. Ama nedense bizim eğitim takvimimiz genellikle böyle ayın 20'siyle 24'ü arasına denk geliyor. Odadaki arkadaşlara soruyorum siz bu işi şey yapmıyor musunuz yani büroda çalışan ya da bu işi yapmak, bu takvime uymak zorunda olan insanlar nasıl gelsinler diye..." şeklindeki görüşü birbirini destekler nitelikte bulgulardır.

Diğer taraftan odaların eğitim konusunda yeterli desteği sağladığını “...TÜRMOB ve Odamız eğitim konusunda yeterli desteği sağlıyor. Işste stajyerlerin eğitimi noktasında sınavların yapılması noktasında herhangi bir sıkıntı yok..." şeklinde ifade eden SMMM (14)'ün görüşü, 
SMMM (17)'nin “...Odalarımız şey açısından güzel, eğitimdir, seminerdir birtakım güncel bilgilerin aktarılmasıdır, çünkü bizde devamlı mevzuat değişiyor. O konularda memnunum yani bir devamlı bir eğitim durumu ya da bilgilerin aktarılması..." şeklindeki görüşünü destekler nitelikte bir bulgudur. SMMM (15) ise bu iki görüşün aksine "Ben oradaki eğitimleri çok kaliteli bulmuyorum... Ciddi atölye çalışmalarının olması gerekiyor... Yani oraya katılan insan... Kafasında bir soru kalmayacak nitelikte olmalı..." şeklinde tam tersi yönünde görüş bildirmiştir. SMMM (15)'in bu görüşüne bir başka açıdan da bakmak yerinde olacaktır. Şöyle ki Odalar tarafından verilen eğitimlere konuşmacı olarak katılan muhasebe meslek mensupları aynı zamanda örtülü bir şekilde kendi reklamlarını da yapabilmektedirler. Gerçekten konu hakkında yeterli bilgi sahibi olmayan konuşmacılar olabildiği gibi aynı şekilde bilgiyi vermekten kaçınan konuşmacılar da olabilmektedir. Bir başka deyişle konuşmacı konuyla ilgili yeteri kadar bilgi vermeyip meslek mensuplarına o konuyla ilgili bir sıkıntı yaşadıklarında başvuracakları kişinin kendisi olduğunu ima etmektedir. Dolayısıyla verilen eğitimlerde hedef kitlenin muhasebe meslek mensupları ve iş adamları olduğu düşünüldüğünde amacın müşteri bulmak olduğu da açıktır. Araştırmacı söz konusu bu durumu bizzat kendisi tez danışmanı ile deneyimlemiştir. ${ }^{11}$

SMMM (13) ile SMMM (9) mesleki kuruluşların siyasi birer kuruluş olduğunu ve beklentilerinin karşılanmadığını ifade etmiştir. SMMM (9) bu görüşünü şu şekilde dile getirmiştir:

SMMM (9): (...) TÜRMOB'dan beklentilerimiz karşılanmıyor tabii. Şimdi karşılanmadığı için ben de bu siyasetin içinde de yer aldım iki dönem, Oda başkanlığına aday oldum, sırf bu sorunları çözme adına elimi taşın altına koyayım dedim. Olmadı. Soğudum yani tamamen soğudum. Çünkü ne TÜRMOB, ne Odalar maalesef mesleğin ileriye gitmesi için pek bir çaba sarf edemiyor. Ya da işte hükümetle o diyalogu kuramadıkları için belki de yapamıyorlar onu. Sonuçta hani şöyle bir şey ülkede işte devletin hükümetin her şeye bakış açısı neyse bizim mesleğe de öyledir yani. Daha çok oy kaygısıyla bir şeyler yapmaya çalıştıkları için biz her zaman her şeyde olduğu gibi geride kalıyoruz. (...) (12.05.2017)

Son olarak YMM (22)'nin “...TÜRMOB'dan beklediğimiz hiçbir şey yoktur yeminli mali müşavirler olarak. Çünkü TÜRMOB'un çok üstünde nitelikleri taşımaktadır. TÜRMOB kendi üyelerinin 90 bini bulan serbest mali müşavirlerle uğraşan onlarla hışır neşir olan yeminli mali müşavirlerle hiç ilgisi olmayan bir gruptur. Bir üst birliktir, bu haliyle, yasadaki düzenlemesiyle. Yeminli mali müşavirlere hiçbir faydası olmadığı gibi çoğu zamanda zarar vermektedir..." şeklindeki görüşü dikkat çekici bir bulgudur.

Elde edilen bulgulardan muhasebe meslek mensuplarının mesleki kuruluşlardan beklentilerinin;

- Odalar tarafından nitelikli eğitimler verilerek meslek mensuplarının mesleki gelişimlerine katkı sağlamaları,

- Haksı rekabeti önleyici denetim mekanizması oluşturmaları (özellikle asgari ücret tarifesinin altında hizmet veren muhasebe meslek mensupları için),

- Mesleğin gerektirdiği etik kurallara aykırı hareket eden meslek mensupları için disiplin cezalarının etkin bir şekilde uygulanması ve

\footnotetext{
11 İlgili deneyim, Eskişehir Serbest Muhasebeci Mali Müşavirler Odası tarafından 11.04.2017 tarihinde düzenlenen araştırmacı ve tez danışmanı Prof. Dr. M. Erkan Üyümez'in bizzat katıldığı bir seminere aittir. Araştırmacı günlüğü, s. 17-22.
} 
- Mesleki kuruluşların siyasi kaygılardan uzak, muhasebe mesleğinin gelişmesi için hareket etmeleri şeklinde olduğu tespit edilmiştir.

Sonuç olarak muhasebe meslek mensuplarının mesleki kuruluşların faaliyetlerini genel olarak yeterli bulmadıklarını ve muhasebe meslek mensupları arasındaki sıkıntıların ciddiyetini gözler önüne sermişlerdir. Muhasebe meslek mensupları arasında özellikle Odaların vermiş oldukları eğitimi yeterli bulup bulmadıklarına dair görüş ayrılıkları vardır. Diğer taraftan mesleki kuruluşların kuruluş amaçlarından birinin de meslek disiplini ve ahlakını korumak olduğu düşünüldüğünde mesleki kuruluşların özellikle Odaların bu amacı gerçekleştiremediği yönünde bir sonuca varılabilir. Yine muhasebe meslek mensupları asgari ücret tarifesinin uygulanışındaki sorunları dile getirmiş ve bu tarifenin altında hizmet veren meslek mensuplarının varlığına dikkat çekmişlerdir. Bu durumun ise haksız rekabete yol açtığını ifade etmişlerdir. Ayrıca burada meslek ahlakına aykırı davranan muhasebe meslek mensupları hakkında da mesleki kuruluşlar tarafından yeterli disiplin cezalarının verilmeyişini vurgulamışlardır.

\subsubsection{Yasa Koyucudan 3568 Sayılı Kanun Bağlamında Beklentiler}

Görüşme yapılan muhasebe meslek mensuplarının hepsi yasa koyucudan 3568 sayılı Kanun'dan beklentilerine yönelik görüş bildirmiştir. Katılımcıların 3568 sayılı Kanun'da hem yeterli hem de yetersiz gördükleri taraflar aşağıda alıntı yapılarak sunulmuş ve yorumlanmıştır.

SMMM (1), muhasebe meslek mensuplarının görev ve sorumlulukları yasada tanımlanmış olmasına rağmen birçok meslektaşının bu kaidelere uymadığını ve uymaya zorlayacak bir yaptırım sisteminin olmadığını dolayısıyla kanunu uygulamada yeterli bulmadığını şu sözlerle ifade etmiştir:

SMMM (1): (...) Birbirlerini kötülemek yoluyla müşteri kapma telaşı içerisine giriyorlar. (...) (...) Tamamen mükellefimi kaybedeceğim korkusuyla nasıl az vergi çıkartıım, nasıl birtakım bilanço hilelerine başvurabilirim. Çünkü doğruyu yansıttığı zaman mükellef sıkıntı yaşayacak. Ondan dolayı birtakım etik kurallara hiç mi hiç uyulmuyor. Bu da Odalar tarafından zaten denetlenmiyor. Ve haksız rekabet gerçekten çok fazla bizim meslekte. (...) (02.12.2016)

SMMM (11), yasada sınırlı yetki verilen denetim görevini yapamadıklarını ve sistemin buna müsaade etmediği belirtirken, YMM (22) ise serbest muhasebeci mali müşavirlerden daha nitelikli olduklarından ayrıma gidilmesi gerektiğini ancak sayısal yetersizlikten dolayı bir baskı grubu oluşturamadıkları dolayısıyla bu durumun dile getirilemediğini belirtmiştir. Ayrıca muhasebe meslek mensuplarına yasa ile verilen denetim yetkisinden rahatsız olduklarını ifade ederek denetim görevini sadece kendilerinin yapması gerektiğini ifade etmiştir. Diğer taraftan yapılan denetimlerin ücretinin denetimi yapılan kişiden alınmasının sıkıntı oluşturduğunu belirterek, ilgili Kanun'da yer alan problemleri şu şekilde aktarmıştır:

YMM (22): (...) Hayır, hiçbir şekilde ihtiyaca cevap vermiyor. Kanun aslında teknik olarak düzgün bir kanun. Teknik yapısı itibarıyla örnek de sayılabilecek bir yasa. Fakat çok büyük handikapları var. íki meslek grubunu serbest mali müşavirlerle, yeminli mali müşavirleri aynı çatı altında toplayan ve yaptıkları işleri de çok fazla tefrik etmeden, ayırmadan düzenlediği bir gerçek. Sayısal çoğunluk serbest mali müşavirlerde. Ama niteliksel olarak farklı bakış açısını taşıyan grup ise yeminli mali müşavirler. Bu iki grubun aynı çatı altında TÜRMOB altında toplanmasını ve temsilini salt sayısal demokrasiyle açıklamak mümkün değil. Bu devamlı huzursuzluk kaynağı. Birinci konu bu. İkinci konu denetim mesleğinin tam ve net olarak yeminli mali müşavirler tarafından yapılması gerektiği halde denetim işini serbest mali müşavirlere de bir miktar sınırlı da olsa veren bir yasa. Bu yönüyle eksik düzenlendi denebilir. 
Üçüncüsü, yapılan denetimlerde denetimi yapılan kişilerden ücret alınmakta. Bu belki liberal ekonomiye göre uygun. Ancak yapılan işin niteliği göz önüne alındığında yasanın düzenlediği yani işi yapılan kişiden, onayı yapılan kişiden tasdiki yapılan kişiden ücret alınması SIkıntılar yaratıyor. Üçüncü eksik tarafı da bu. Serbest mali müşavirler sayısal olarak çok olmaları, 90 bin civarında olmaları, bizim de sayımızın 4500 civarında olması onların matematiksel olarak üstünlük sağladığı hissini vermekte. Bu nedenle asla geçinmek mümkün değil. Bu yasa ortamında iki meslek grubunun geçinmesi mümkün değil. Bu tür eksiklikleri var. Onun dışında teknik olarak düzenlenmesi fena değil. Ama asıl bu eksikliklerin giderilmesi için baştan kaleme alınması kaçınılmaz. (...) (20.06.2017)

SMMM (14) ise yasada tanımlanmamış olmasına rağmen rutin işler dışında birçok iş yaptıklarını ve bu durumdan memnuniyetsizliğini dile getirmiştir. Ayrıca yasal olarak düzenledikleri belgelerin devlet çatısı altında bulunan farklı kurumlara ayrı ayrı iletmek zorunda oldukları için bu sorumlulukların iş yüklerini artırdığını şu şekilde ifade etmiştir:

SMMM (14): (...) Yasal düzenlemeler var özellikle bizim sıkıntı yaşadığımız alanlar kanunda düzenlenmeyen noktalar, bizim çeşitli platformlarda angarya olarak adlandırdığımız işler var. İste ne bileyim TÜiK raporları. Bunlar tamamen bizim meslek yasamızda yer almayan iş olarak bizim alanımıza girmeyen ancak mükelleflerin de kapasiteleri anlamıyla yapmalarının mümkün olmadığı bu yüzden angarya olarak bizim üzerimize kalan işler. Artı birde yasal anlamda bizi sıkıntıya sokan nokta, karşımızda yani biz üçlü bir saç ayağı olarak görüyoruz. Mükellef, mali müşavir ve devlet. Devleti burada birden fazla ayağa bölmek durumunda kalmak sıkıntı yaratıyor. Nedir işte muhataplarımızdan bir tanesi Vergi İdaresi bir diğer muhatabımız SSK, işte öbür taraftan Sanayi Ticaret il Müdürlüğü gibi farklı kurumlar, devlet çatısı altında bu sacayağının diğer bir yapısı. Mevcut bir bilgiyi bir şekilde devlete ilettikten sonra aynı bilgiyi devletin farklı kanallardan tekrar tekrar istemesi bunun size bu bilginin verilmeyişinin ya da hatalı verilişinin yaptırım olarak karşınıza çıkması anlamsız ve can sıkıcı geliyor. (...) (31.05.2017)

SMMM (24)'ün ise "...Angarya işlerin önüne hiçbir zaman geçilmedi. Bir kâtip gözüyle gözüküyoruz. Yani mükellef açısından da. Maliye açısından da yani aynı şekilde görülüyoruz..." şeklindeki görüşü, SMMM (14)'ün yukarıdaki görüşünü destekler niteliktedir.

Bir diğer dikkat çekici nokta ise şudur; serbest muhasebeci mali müşavirler kendilerini daha çok avukatlar ile kıyaslarken, yeminli mali müşavirler ise kendilerini vergi müfettişleri ile kıyaslamaktadırlar. Örneğin, SMMM (19) bu durumu “...Bizim mesleğe benzer olarak avukatları düşündügüumüz zaman çok daha iyi haklara sahip ve çok daha iyi yetişme şartları var. Stajyer meslek mensuplarına onların yaptıklarıyla bizim yaptıklarımız aynı değil. Aynı şekilde mesleğin ilerlemesi aşamasında yani çalışma aşamasında da sahip olduğumuz haklar bir avukatlara baktığımız zaman çok çok az düzeyde kaldığını düşünüyorum..." şeklinde ifade ederken, YMM (4) ise "...Yeminli mali müşavirlere neredeyse bir vergi müfettişinin sorumluluklarını vermiş. Ama yetki açısından yeminli mali müşavir müfettişin yetkisinin 10'da birine sahip değil. Yeminli mali müşavir vergi dairesinin vergi kayıtlarıyla ilgili bilgi işlem sistemini kontrol edip oradan bir müşterinin profilini göremez. Ama vergi müfettişi onu görür. Yeminli mali müşavir bankaya veya özellikle bankaya veya bir kuruma yazı yazdığında kurum onun cevabını savsaklar doğru düzgün cevap vermez veya çok uzun sürede geç cevap verir. Bu nedenle araştırma ve inceleme şeyi çok geç, zordur yeminli mali müşavirin. Bunlar işin handikapları. Yani bir müfettiş kadar sorumluluk verilen ama müfettişin yarısı kadar yetki verilmeyen bir meslek..." şeklinde ifade etmiştir. 
Elde edilen bulgular neticesinde 3568 sayılı Kanun'dan beklentiler ve eksik bulunan yönler;

- Kanun'da muhasebe meslek mensuplarına verilen sorumlulukların fazla yetkilerin ise sınırlı olması,

- Muhasebe meslek mensupları için yasada tanımlanmış görev ve sorumlulukların yerine getirilmesi ile ilgili denetimlerin çeşitli nedenlerle yapılamayışı,

- Muhasebe meslek mensuplarının Kanun'da tanımlanmayan görevleri de yapıyor olmaları ve

- Serbest muhasebeci mali müşavirlerden daha nitelikli oldukları yönünde görüş bildiren yeminli mali müşavirlerin ilgili Kanun kapsamında statü farklılaştırılmasına gidilmesini talep etmeleri şeklindedir.

Sonuç olarak muhasebe mesleğinin yasal statüye kavuşturulması açısından 3568 sayılı Kanun'un önemli bir yeri vardır. Buna karşın bu yasa ile düzenlenmesi gereken birçok konu vardır. Öncelikle görev, sorumluluk ve yetki noktasında sorunların olduğu tespit edilmiştir. 3568 sayılı Kanun'da muhasebe meslek mensupları için tanımlanan görevler dışında angarya olarak tabir ettikleri işleri yaptıklarını, muhasebe meslek mensupları tarafından hazırlanan bazı belgelerin farklı kurumlara iletilmek zorunda oluşu ve tüm bu durumların onlarda yük oluşturduğu dolayısıyla ilgili Kanun ile bu sıkıntıların giderilmesi beklenmektedir. Diğer taraftan yeminli mali müşavirler tarafından da serbest muhasebeci mali müşavirlere ilişkin birtakım sıkıntıların olduğu belirtilerek özellikle statü farklılaştırılması talep edilmektedir. Ayrıca muhasebe meslek mensubu olmak için ilgili Kanun'da ekstra birtakım özel şartların olması mesleğin standartlarını yükseltmesi açısından olumlu görülmektedir.

\subsubsection{Vergi Mükelleflerinin Beklentileri ve Aldıkları Hizmetler}

Vergi mükellefleri ile yapılan derinlemesine yarı yapılandırılmış görüşmelerden elde edilen verilerden ana tema olarak "Beklentiler ve alınan hizmetler" temasına ulaşılmıştır. Bu ana temanın alt temaları ise "Muhasebe meslek mensuplarından", "Mesleki kuruluşlardan", "Muhasebe meslek mensuplarının mükelleflerden" ve "Devletten ve vergi idaresinden" şeklinde dörde ayrılmıştır. illgili temaların frekans dağılımı ${ }^{12}$ aşağıdaki şekil yardımıyla açıklanmıştır.

\footnotetext{
${ }^{12}$ Frekans dağılımı, vergi mükelleflerinin görüşlerinin sayısını ifade etmektedir.
} 
Şekil 3.2. "Beklentiler ve Alınan Hizmetler" Adlı Ana Tema ve Alt Temalar

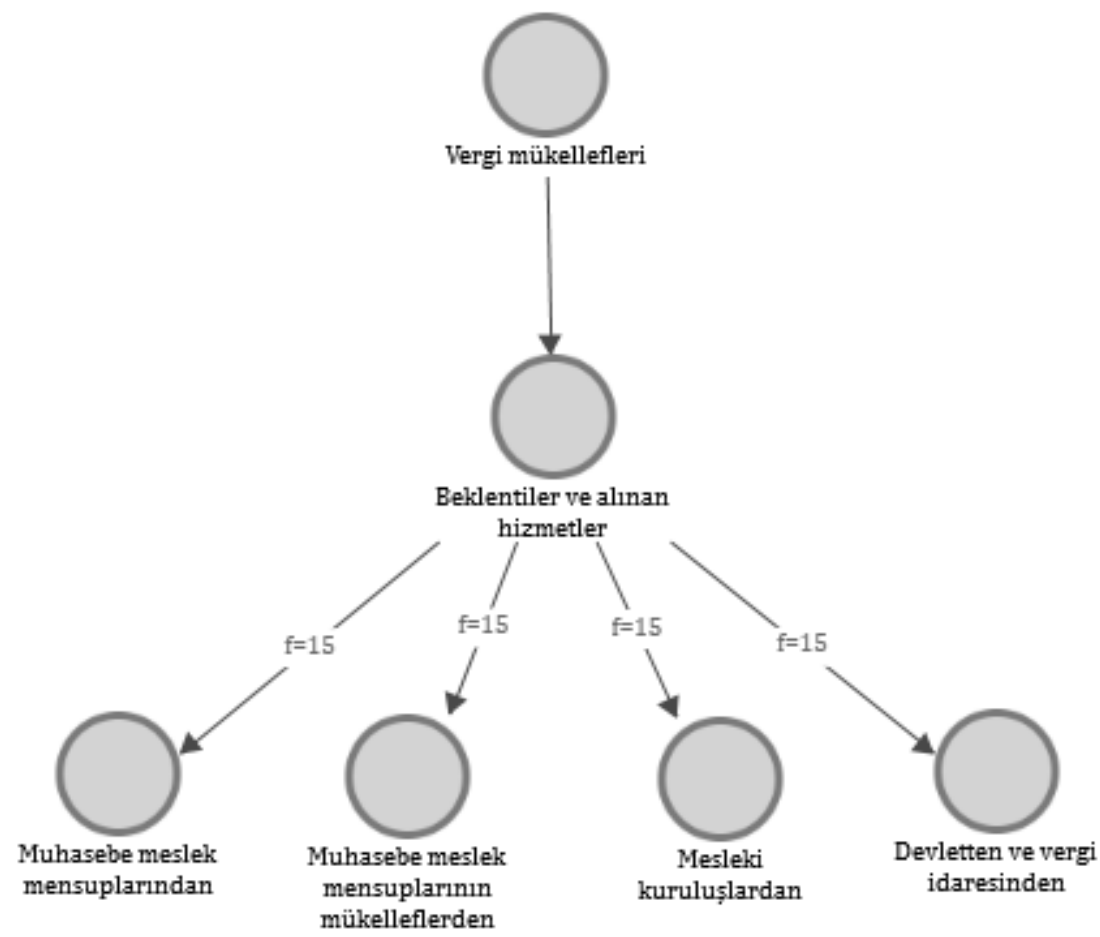

\subsubsection{Muhasebe Meslek Mensuplarından Beklentiler ve Alınan Hizmetler}

Kendileriyle görüşme yapılan vergi mükelleflerinin hepsi muhasebe meslek mensuplarından beklentilerine ilişkin görüş bildirmiştir. Mükellef (6), muhasebe meslek mensubundan beklentisini şu sözlerle ifade etmiştir:

Mükellef (6): (...) Mali müşavir hem devletin hakkını koruyacak, vergisini tam verecek ama aynı zamanda mükellefe verilen devletin birtakım şeyleri vardır bu vergi açısındaki menfaatleri olan kanunları çok iyi takip etmeliler. Yani o ne diyeyim devletin verdiği indirimlerden, teşviklerden de yararlandırmalı mükellefini. Bazı muhasebeciler bunlar klasik şeyden gidiyorlar yani bir türlü o yönlerden gitmiyorlar. Baştan başladığı gibi kanunu günlük takip etmiyorlar. Kanunun değişikliklerine bakmıyorlar. Başında ne öğrenirse düz muhasebe tarzı dediğimiz bir tavirla devam ettikleri zaman mükellefini geliştiremiyorlar. Mükellef de gelişmeli ki devletine devamlı vergi versin. (...)

(...) Bir aile ortamı gibi. Ailede nasıl ki problemlerimizi iç içe anlatırsınız doğru yanlış ne varsa bir problem yaşıyorsanız onu birbirinize aktarırsanız çare bulma imkânları vardır. $\mathrm{O}$ açıdan muhasebeciyle işte iş sahibi çok birbirini iyi bilmeliler. Birbirlerine iyi güvenmelilerdir. (...)

(...) Problem geleceğini önceden hissetmeli. Nedir bunun işte çeşitli vergiler çıkacaktır, şunlar, bunlar önceden işverene haberdar etmeliler. (...) (02.08.2017)

Mükellef (12), muhasebe meslek mensubundan beklentisini "...Yaptığımız ticarette selamete çıkarma açısından en ufak bir problem olmadan işleri götürmesidir..." şeklinde dile geti- 
rirken, Mükellef (1) ise muhasebe meslek mensubundan beklentisini "... Beklentim beni zaman zaman uyarması, yardımcı olması her konuda..." şeklinde ifade etmiştir.

Diğer taraftan Mükellef (2)'nin “...Benim en büyük beklentim bana müşavirlik hizmetini verebilmesi gerekiyor. Ama bu da şimdi dışarıdan tutulan bir muhasebeyle ne kadar olabilir bu da tartışılır..." şekildeki görüşü ile Mükellef (15)'in “...Mali müşavirim üç tane eleman çalıştırıyor kendi de bürokrat gibi maşallah oturuyor hani aynı bu bürokrat usulü böyle bir şey olamaz. Işçisi bana telefon ediyor abi bugün evrakları getir ben zaten hazırlamışım o sadece oraya kaydediyor. Böyle sistem olmaz bence..." şeklindeki görüşü birbirini destekler nitelikteki bulgulardır. Bu bulgular mükelleflerin muhasebe meslek mensuplarından gerçek anlamda bir müşavirlik hizmeti almak istediklerini ve muhasebe meslek mensuplarıyla uzaktan değil de fiziki görüşmeler şeklinde bir ilişki kurmak istediklerini göstermektedir. Mükellef (15)'in söyleminden ise ayrıca muhasebe meslek mensupları tarafından kendilerine verilen hizmeti küçümsediği de anlaşılmaktadır.

Görüş bildiren mükelleflerden yedisi ${ }^{13}$ ise muhasebe meslek mensuplarından vergisel işlemler dışında bir hizmet almadığını belirtmiştir. Örneğin muhasebe meslek mensubundan kendisine yatırım danışmanı bulmasını istediğini belirten Mükellef (3)'ün "...Mesela KOSGEB'e bir yatırım için müracaat etmek istedim. Bununla ilgili bir danışman bulmasını istedim..." şeklindeki ifadesi ile Mükellef (15)'in "...Sadece faturalar girişler çıkışlar, başka şeyimiz yok..." şeklindeki söylemi, mükelleflerin vergisel işlemler dışında bir hizmet almadıklarını gösteren ve birbirlerini destekleyen nitelikte bulgulardır.

Elde edilen bulgulardan mükelleflerin muhasebe meslek mensuplarından beklentilerinin:

- Muhasebe meslek mensubunun günceli takip etmesi ve mükellefleri bilgilendirmesi,

- Hem devletin hakkını hem de mükellefin hakkını gözeterek akılcı çözümler sunması,

- Vergisel işlemler dışında danışmanlık hizmeti de vermesi,

- Mükellefler ile olan iletişimlerini bürolarından ya da çalıştırdıkları elemanlar aracılığı ile değil de bizzat mükellefin iş yerinde sürdürmeleri gerektiği veya bizzat muhasebe meslek mensubunca mükellefin işleri ile gerçekten ilgilenilmesi ve

- Devlet ile vergi idaresi arasında bir köprü görevi görerek mükellefin sorun yaşamasına engel olmak şekilde olduğu görülmektedir.

Sonuç olarak görüş bildiren mükelleflerin çoğu (büyük ölçekli işletme sahibi olan mükellefler hariç) muhasebe meslek mensuplarının beklentilerini tam olarak karşılamadığı yönünde görüş bildirmişlerdir. Dolayısıyla büyük ölçekli bir işletmeye sahip olan mükellefin beklentisi ile aldığı hizmetin kalitesi bu noktada farklılık gösterebilmektedir. Küçük ve nispeten orta ölçekli işletme sahipleri, muhasebe meslek mensuplarının beklentilerini tam olarak karşılamadıklarını aldıkları hizmetin vergisel işlemler dışına çok fazla çıkmadığını ifade etmişlerdir.

${ }^{13}$ Mükellef (1), Mükellef (3), Mükellef (4), Mükellef (5), Mükellef (12), Mükellef (14), Mükellef (15). 


\subsubsection{Mükelleflerin Gözüyle Muhasebe Meslek Mensuplarının Mükelleflerden Beklen- tileri}

Araştırmaya katılan vergi mükelleflerinin hepsi muhasebe meslek mensuplarının kendilerinden beklentilerine ilişkin görüş bildirmiştir. Mükellef (1)'in, “...Anlaşmış olduğumuz belli bir ücret vardır. O ücretin karşılığında benim işimi yapacak ben de o işin bedelini ödeyeceğim ona. Beklediği bu, başka bir şey yoktur..." şeklindeki görüşü, Mükellef (10)'un "...Beklentileri diye bir şey yok... Neyse alacağı onu alıyor yani başka bir şey bizden bir talebi olmuyor..." şeklindeki görüşü ile Mükellef (12)'in ise "...Bizden beklentisi tatmin edici ücret almak..." şeklindeki görüşü, muhasebe meslek mensuplarının kendilerinden öncelikli olarak verdikleri hizmetin bedelini almak olduğunu belirten birbirlerini destekler nitelikteki bulgulardır.

Diğer taraftan Mükellef (9)'un muhasebe meslek mensubunun kendisinden beklentisini ifade ediş şekli diğer birçok katılımcı görüşünden dikkat çekici bir şekilde ayrılmaktadır. Katılımcı meslek mensubunun kendisinden beklentisini ayrıntılı olarak şu şekilde ifade etmiştir:

Mükellef (9): (...) Onların bizden beklentileri şöyle, tabii onların da vergiyle ilgili olsun, onun dışında faturaların işte zamanında ulaşması, ondan sonra işte ne bileyim fiş değil fatura alınması, ondan sonra bunların zamanında muhasebe birimine ulaştırıması, bunlar. Onlar bizden bunları bekliyorlar. Onun dışında örneğin işte bir mal sevk ediyorsunuz, sevk irsaliyesi kesiyorsunuz işte 7 gün içerisinde bunun faturası düzenlenmesi gerekiyor. Beklentiler bunlar bizden, isteniyor. Onun dışında yani harcamalarla ilgili, onun dışında tabii her şey bizde bütçeyle gidiyor. O bütçe çerçevesinde kalmamı isteniyor. Yani bütçelerin bazen örneğin, bir örnek vereyim size, akaryakıtla ilgili bir yıllık bütçe yapmışsınız bir birime, ne demişsiniz bu birimde 200 bin liralık akaryakıt bütçelemişsiniz. Muhasebe 200'e doğru yaklaştığı zaman bize uyarı geliyor diyor ki işte 9 ay oldu siz 1 yıllık 200 bin lira planladınız 9 ay oldu 180 bin lira harcadınız. Böyle giderseniz bütçeyi aşabiliyorsunuz diyorlar. (...) (03.08.2017)

Elde edilen bulgular;

- Muhasebe meslek mensuplarının kendilerinden öncelikli olarak tatmin edici bir ücret beklediklerini ve

- Muhasebe meslek mensuplarının ücretten ziyade kendilerinden yasal yükümlülükleri gereği gibi yerine getirmeleri doğrultusunda beklentileri olduğunu dile getiren mükelleflerin bulunduğunu göstermektedir.

Sonuç olarak araştırmaya dâhil olan küçük ve orta ölçekli işletme sahiplerinden oluşan mükellef grubunun büyük çoğunluğu muhasebe meslek mensubunun kendisinden özellikle tatmin edici bir ücret talep ettiği yönünde görüş bildirmiştir. Büyük ölçekli işletme sahibi mükellefler ise muhasebe meslek mensubunun kendisinden talep edeceği ücretten ziyade özellikle yasal prosedürlerin doğru bir şekilde ve zamanında yerine getirilmesi konusunda beklentilerinin olduğunu ifade etmiştir.

\subsubsection{Mesleki Kuruluşlardan Beklentiler ve Alınan Hizmetler}

Araştırmaya katılan mükelleflerin hepsi kayıtlı oldukları Odalardan beklentilerine ya da aldıkları hizmetin yeterli olup olmadığına dair görüş bildirmiştir. Mükelleflerden beşi ${ }^{14}$ Odaların beklentilerini karşıladığı yönünde görüş bildirirken, diğer beşi ${ }^{15}$ beklentilerini karşılamadıkları-

\footnotetext{
${ }^{14}$ Mükellef (3), Mükellef (4), Mükellef (6), Mükellef (9), Mükellef (13).

${ }^{15}$ Mükellef (2), Mükellef (7), Mükellef (8), Mükellef (14), Mükellef (15).
} 
nı, üçü ${ }^{16}$ Odalardan beklentisinin olmadığını, kalan ikisi ${ }^{17}$ ise Odalara ihtiyaç duymadıkları yönünde görüş bildirmiştir.

Odalardan beklentisini karşıladığı yönünde görüş bildiren mükelleflerden Mükellef (6), bu konudaki düşüncesini şu şekilde açıklamıştır:

Mükellef (6): (...) Meslek Odaları da yönlendirici olmalılar. (...)

(...) Ticaret Odası son zamanda iyi. Yani bu konferanslar verdirtiyorlar. Efendim eleman eğitimi veriliyor. Bu yönden hakikatten insanları aydınlatmalılar yani. Bunlar belki bugün görülmeyebilir ama ileriye doğru çok faydasını göreceğiz. (...)

(...) Çünkü hakikatten insanlarımız aydınlanmaya başladı. Ticareti öğrenmeye başladı ve iyi esnaf da yetişiyor bakıyorum. Yani daha düzgün daha prensipli esnaflar da yetişmeye başlıyor. (...) (02.08.2017)

Odaların beklentisini karşılamadığı yönünde görüş bildiren Mükellef (2) ise, bu beklentisini "...Odaların mükellefleri bilinçlendirmesi lazım..." şeklinde ifade etmiştir. Diğer taraftan yine Mükellef (15)'in "...Ben açık net konuşayım aidat toplamaktan başka hiçbir şey yapmıyor..." şeklindeki görüşü ile Mükellef (7)'nin “...Şimdi Odaların bize hiçbir faydası yok ne Sanayi Odasının var ne Ticaret Odasının var. Hepsi bizden aidatı alıyor, başka bir şey yapmıyor..." şeklindeki görüşü birbirini destekler nitelikteki bulgulardır.

Yine Oda yönetiminde uzun yıllar görev alan Mükellef (8)'in “...Odalarda particilik olduğu içinde bir şey olmuyor..." şeklindeki görüşü ise bir diğer dikkat çekici bulgudur.

Elde edilen bulgulardan mükelleflerin mesleki kuruluşlardan beklentilerinin;

- Sürekli eğitimler verilerek daha bilinçli mükellefler olmalarına katkı sağlamaları,

- Mükelleflerin piyasada yaptıkları işle ilgili onları bir adım ileriye götürecek ufuk açıcı fikirler sunmaları ve

- Odaların kuruluş amaçları yönünde hareket etmeleri şeklinde olduğu görülmektedir.

Sonuç olarak görüş bildiren mükelleflerden mesleki kuruluşların beklentilerini karşılayıp karşılamadığı yönünde görüş farklılıkları vardır. Mükelleflerden bazıları odaların sadece aidat topladıklarını dolayısıyla kendilerine bir faydası olmadığını belirtirken bazıları ise mesleki kuruluşlar tarafından verilen eğitimlerin yeterli olduğunu ve bu durumdan memnuniyetlerini dile getirmişlerdir.

\subsubsection{Devletten ve Vergi İdaresinden Beklentiler ve Alınan Hizmetler}

Araştırmaya katılan mükelleflerin hepsi devletten ve vergi idareleri tarafından beklentilerine ya da aldıkları hizmetlere ilişkin görüş bildirmiştir. Mükelleflerden dördü ${ }^{18}$ vergi dairelerinde çalışan memurlar ile olan ilişkilerinden memnuniyetlerini dile getirirken, mükelleflerden üçü ${ }^{19}$ ise elektronik sistem üzerinde birçok işlemi gerçekleştirdiklerini ve bu durumdan memnuniyetlerini vurgulamıştır. Örneğin Mükellef (13) bu konudaki görüşünü “...Elektronik ortam-

\footnotetext{
${ }^{16}$ Mükellef (1), Mükellef 5), Mükellef (12).

${ }^{17}$ Mükellef (10), Mükellef (11).

${ }^{18}$ Mükellef (1), Mükellef (8), Mükellef (9), Mükellef (10).

${ }^{19}$ Mükellef (2), Mükellef (7), Mükellef (13),
} 
da müthiş hizmet veriyorlar..." şeklinde ifade etmiştir. Mükelleflerden dördü ${ }^{20}$ ise devlet ya da vergi idaresiyle herhangi bir sıkıntı yaşamadığını ifade etmiştir.

Görüşme yapılan mükelleflerden ikisi ${ }^{21}$ kendilerine devlet tarafından mükelleflere sağlanan matrah artırımı ya da vergi afları gibi uygulamalardan memnuniyetlerini dile getirmiştir. Örneğin Mükellef (14), bu konudaki memnuniyetini şu şekilde ifade etmiştir:

Mükellef (14): (...) Özellikle bu son senelerde çok kolaylıklar sağlıyor. Daha eskiden zorluklar çoktu. Mesela ben öyle günler biliyorum vergi memurlarının burada sanki terörle mücadele şubesi gibi caddelerde kol kol gezip de mükellefleri çok sıkıştırdığını biliyorum ben. Özellikle $80^{\prime}$ li yıllarda çok zorluklar çektik biz. Hâlbuki şimdi devlet hem bilgilendiriyor hem kolaylaştırıyor yani işi. (...)

(...) Ne yapıyorlar bunlar matrah artırmasına gidiyorlar ara sıra mesela matrah artırması. Mesela adam diyor ki Maliye Bakanlığı genelge mi artık ne çıkarıyor. Geçmiş 5 yıla ait yıllık şu kadar matrah artıımı yaparsan bu şeylerini diyor sorgulamaktan kaldıracağız. (...)

(...) Şu anda devletin bu politikası iyi yani insanları sıkışıımaktan ziyade bilgilendirmek çok önemli. Bu anda bu da oluyor yani müsamahalı davranıyorlar biraz da yani. Bu müsamahalı davranmak bence daha iyi netice veriyor. (...) (05.08.2017)

Diğer taraftan mükelleflerden biri ${ }^{22}$ ise matrah artırımı ya da vergi afları gibi uygulamalardan rahatsızlığını şu şekilde dile getirmiştir:

Mükellef (4): (...) Şimdi şöyle biliyorsunuz Türkiye'de son yıllarda özellikle biriken borçları taksitlendirme, faizlerini silme gibi birçok şeyle karşılaşıyoruz. Ve bu karşılaştığımız şeylerin içerisinde ben ödüyorum salak mıyım diyoruz. (...) (19.06.2017)

Son olarak Mükellef (6) ise beklentisini şu şekilde açıklamaya çalışmıştır:

Mükellef (6): (...) Mesela yatırdığımız bir şeyi daha sonradan yatırımamış gibi bize cezai durumlar çıkıyor. Biz araştıııp buluyoruz makbuzunu, öyle kapanıyor. O tür şeylerde de dikkat etmeliler. Yani yatırılan bir parayı ikinci defa istenmesin. (...) (02.08.2017)

Elde edilen bulgular;

- Mükelleflerin vergi dairelerinde çalışan memurlar tarafından iyi muamele gördüklerini,

- Ödeme işlemlerinin internet üzerinden yapılıyor olmasının mükelleflere oldukça kolaylık sağladığını,

- Mükellefler tarafından yapılan ödemelerin, sonrasında vergi idaresi tarafından tekrar talep edilebildiğini ve bu durumun mükellefler üzerinde evrakları eksiksiz bir şekilde muhafaza etme yükü oluşturduğunu,

- Vergi sisteminde matrah artırımı, vergi affı gibi uygulamalardan memnuniyetlerini dile getiren mükellefler olduğunu ve

- Diğer taraftan matrah artarımı, vergi affı gibi uygulamaların vergisini düzenli ödeyenler için adaletsiz olduğu yönünde görüş bildiren mükellef olduğunu göstermektedir.

${ }^{20}$ Mükellef (3), Mükellef (5), Mükellef (11), Mükellef (12).

${ }^{21}$ Mükellef (14), Mükellef (15).

${ }^{22}$ Mükellef (4). 
Sonuç olarak mükellefler ile yapılan görüşmelerden elde edilen verilerin, mükelleflerin devletten ve vergi idaresinden beklentilerinden daha çok vergi idareleri tarafından verilen hizmetleri ve devletin sağlamış olduğu vergi ödeme kolaylıklarını değerlendirme şeklinde olduğu görülmektedir. Genel olarak vergi idaresinden çok fazla beklenti oluşmamasının nedeni mükellefler adına muhasebe meslek mensuplarının vergi idareleriyle muhatap olması olabilir.

Mükellefler özellikle vergi idarelerinin otomasyon sistemleri sayesinde kolaylıkla vergi ödemelerini gerçekleştirdiklerini belirtmişlerdir. Vergi idarelerinin değişen yapısına dikkat çeken mükellefler özellikle son yıllarda vergi idarelerinin mükellef odaklı bir yaklaşımı benimsediklerini ifade etmişlerdir. Diğer taraftan devletin vergi tahsilatını artırmak için yaptığı yapılandırma, vergi afları gibi düzenlemeler konusunda mükellefler arasında görüş farklılıkları vardır. Vergisel yükümlülüklerini zamanında yerine getiren mükellef için bu durum adaletli ve doğru karşılanmamaktadır. Diğer bazı mükellefler ise bu tür düzenlemeleri ödemelerde yapılan kolaylıklar olarak görmüş ve memnuniyetlerini dile getirmişlerdir.

\section{Sonuç}

Çalışmada elde edilen verilerden yola çıkarak, muhasebe meslek mensuplarının mükelleflerden öncelikli olarak anlaştıkları ücretin zamanında tahsil edilmesi, sonrasında ise yasal yükümlülüklerinin zamanında yerine getirilmesi anlamında beklentilerinin olduğu tespit edilmiştir. Mükelleflerin muhasebe meslek mensuplarından beklentileri ise, vergi yükümlülüklerinin doğru bir şekilde gerçekleştirilmesi, dolayısıyla devlet ile karşı karşıya gelmelerine neden olabilecek bir sorun yaşamak istememeleri şeklindedir.

Araştırmanın mükellef grubu içerisindeki katılımcılarından küçük ve orta ölçekli işletme sahipleri ile büyük ölçekli işletme sahiplerinin görüşleri arasında da farklılıklar bulunmaktadır. Küçük ve orta ölçekli işletme sahiplerinden oluşan mükellef grubunun büyük çoğunluğu muhasebe meslek mensuplarının kendilerinden özellikle önemli tutarda bir ücret talep ettiği yönünde görüş bildirmiştir. Büyük ölçekli işletme sahibi mükellefler ise muhasebe meslek mensubunun kendilerinden talep edeceği ücretten ziyade özellikle yasal prosedürlerin doğru bir şekilde ve zamanında yerine getirilmesi konusunda beklentilerinin olduğunu ifade etmiştir. Bu görüş farklılıklarından yola çıkarak, küçük ve orta ölçekli mükelleflerin vergi yüklerini ve vergi yükümlülüklerini yerine getirme maliyetlerini düşürmeye odaklandıkları, buna karşın büyük ölçekli mükelleflerin ise daha nitelikli hizmet talep ettikleri söylenebilir. Özellikle küçük ve orta ölçekli mükellef grubuyla çalışan muhasebe meslek mensuplarının hem yasal yükümlülükler hem de ücret konusunda sıkıntılar yaşadıkları anlaşılmaktadır. Serbest muhasebeci mali müşavirlerin bir kısmı çalıştıkları mükellef grubunun bilinçli olmadığı yönünde görüş bildirirken yeminli mali müşavirler için aynı şeyi söylemek mümkün değildir. Çünkü onlar daha büyük mükellef grubuna hizmet verdikleri için çalıştıkları mükellef gruplarının birçok konuda bilinçli olduklarını ve mükelleflerin kendilerine sunulan hizmet karşılığı tahakkuk eden ücretlerini zamanında ödemeleri noktasında da çok fazla sıkıntı yaşamadıklarını belirtmişlerdir. Dolayısıyla muhasebe meslek mensupları arasında olan statü farklılıkları hizmet verdikleri mükellef grubunda da görülmekte ve bu noktada beklentiler de farklılık gösterebilmektedir.

Muhasebe meslek mensupları ayrıca mesleki kuruluşların faaliyetlerini genel olarak yeterli bulmadıklarını, özellikle asgari ücret tarifesinin uygulanışındaki sorunların var olduğunu, haksız rekabet ortamının oluştuğunu ve meslek ahlakına aykırı davranan muhasebe meslek mensupları hakkında da mesleki kuruluşlar tarafından yeterli disiplin cezalarının verilmediği gibi sorunların olduğunu belirtmiştir. 
Sonuç olarak elde edilen bulgulardan hem muhasebe meslek mensuplarının hem de vergi mükelleflerinin ne tür beklentilerinin olduğu ve bu beklentilerin aynı zamanda hangi sorunları gün ışı̆̆ına çıkardığı tespit edilmiştir. Bu sorunların çözümü halinde vergi gelirleri artacak dolayısıyla vergi uyumu da sağlanmış olacaktır.

\section{Kaynaklar}

Aydemir, Oğuzhan (2015), "Muhasebe Meslek Mensuplarının Karşılaştıkları Sorunlar ve Beklentiler", Muhasebe ve Finansman Dergisi, No. 67, 71-84.

Creswell, John W. (2007), Educational Research: Planning, Conducting, and Evaluating Quantitative, Prentice Hall Upper Saddle River, NJ: Pearson/Merrill Education.

Deran, Ali; Beller, Beyhan (2017), "Muhasebe Meslek Mensuplarının Karşılaştıkları Sorunlar ve Bağlı Bulundukları Meslek Odasından Beklentileri Üzerine Bir Araştırma", Muhasebe ve Denetime Bakış, Vol. 16, No. 50, 37-56.

İbiş, Cemal (2002), Bilgi Çağında Muhasebecilik Mesleğinin Geleceği ve Yeni Muhasebeci Kimliği. XVII. Türkiye Muhasebe Kongresi, TÜRMOB Yayınları-199, 132-141, İstanbul.

Kalaycı, Şeref; Tekşen, Ömer (2006), “Muhasebecilik Mesleğinde Karşılaşılan Sorunlar ve Çözüm Önerileri: Isparta il Merkezi Uygulaması", Muhasebe ve Finansman Dergisi, No. 31, 90-101.

Merriam, Sharan B. (1998), Qualitative Research and Case Study Applications in Education, San Francisco: Jossey-Bass.

Nalbantoğlu, Rıfat (2003), “Muhasebe Uygulamaları Konusunda Meslek Mensuplarının Bakış Açıları”, VI. Muhasebe Denetimi Sempozyumu'nda Sunulmuş Bildiri Özeti, http://archive.ismmmo.org.tr/docs/sempozyum /06Sempozyum/5Oturum/RifatNalbantoglu.pdf, (Erişim: 10.02.2018).

Patton, Michael Quinn (1987), How to Use Qualitative Methods in Evaluation, CA: Sage.

Suadiye, Gülhan; Yükselen, Cemal (2001), "Mükelleflerin ve Muhasebecilerin Birbirlerinden Beklentileri: Hatay Illinde Bir Araştırma”, Mali Çözüm Dergisi, No. 56, 24-36.

Tuğay, Osman; Tekşen, Ömer (2014), "Muhasebe Meslek Mensuplarının Sorunları: Burdur İlinde Bir Araştırma”, Süleyman Demirel Üniversitesi Iktisadi ve İari Bilimler Fakültesi Dergisi, Vol. 19, No. 1, 223-232.

Yıldırım, Ali; Şimşek, Hasan (2013), Sosyal Bilimlerde Nitel Araştırma Yöntemleri, Ankara: Seçkin Yayıncılık. 


\section{Extended Summary}

\section{Expectations and Problems of Accounting Professionals and Taxpayers: A Qualitative Study}

The determination of the expectations and problems of accounting professionals and taxpayers from each other and the people and institutions they are associated with will ensure that tax revenues are collected in a healthier way in the long term and increase of tax compliance. In this context, based on the expectation that these expectations and determination of the problems will be more objective and realistic, the qualitative research method was used in the research and the research was designed as a case study. The research question based on the research is "What are the expectations of accounting professionals and taxpayers? What are the things happening?". First of all, accounting professionals and taxpayers, who are the participant group of the research, were selected with "snowball sampling", which is one of the purposeful sampling methods. Care has been taken to ensure that the accounting professionals to be interviewed are experienced in their selection and that taxpayers have been operating in their business for many years.

Of the 25 professional accountants, one of the participant groups of the research, 18 were freelance accountants and 7 were sworn financial advisors. Professional experience of accounting professionals vary between 3 and 39 years. Another group of participants, consisting of 15 taxpayers, consists of income taxpayers and taxpayers who are related to corporate taxpayers. In this study, in-depth semi-structured interviews were conducted using the "interview" technique to collect data. In-depth semi-structured interviews with both accounting professionals and taxpayers were conducted face to face using a voice recorder. Validity and reliability studies were carried out at the validity committees of the field specialist, qualitative research specialist and researcher at certain intervals during each stage of the preparation, implementation and reporting of the interview questions. The data obtained in the research were analyzed through inductive analysis, which is one of the qualitative data analysis methods. The analysis process is coding data, finding themes, editing codes and themes, and defining and interpreting the findings. Analysis of the research data was carried out with the help of one of the computer-aided qualitative data analysis program, NVivo 11 Pro.

The main theme named "Expectations" and sub-themes related to this main theme were obtained from the data obtained from the in-depth semi-structured interviews with professional accountants. These sub-themes are composed of three sub-themes: "Taxpayers", "Professional organizations" and "Within the context of Law No. 3568" from the legislator. In addition, the sub-theme "From Taxpayers" is divided into two as "in terms of legal obligations" and "financial terms". According to the findings obtained from the data collected within the scope of the research, it is stated that accounting professionals have some legal expectations from taxpayers, but some taxpayer groups do not comply with these legal obligations. It is very important to comply with these legal obligations in terms of timely and correct work and transactions. On the other hand, the fact that the members of the profession want to receive the amount corresponding to their labor and time on time and that this request is not fully fulfilled also indicates the existence of problems. Accounting professionals also have some expectations from professional organizations and the state. They highlighted that accounting professionals do not find the activities of professional organizations sufficient and the seriousness of the problems among professional accountants. There are differences of opinion among accounting professionals on whether the Chambers find the training they have provided sufficient. On the other hand, considering that one of the establishment purposes of professional organizations is to protect professional discipline and morality, it can be concluded that professional organizations, especially Chambers, cannot achieve this goal. Again, accounting professionals expressed the problems in the implementation of the minimum wage tariff and drew attention to the presence of the professional members serving under this tariff. They stated that this situation caused unfair competition. In addition, there is a great deal of opinion that accounting professionals have high liability and limited powers.

From the data obtained from in-depth semi-structured interviews with taxpayers, the theme of "Expectations and services received" was reached as the main theme. The sub-themes of this main theme are divided into four from "Professional accountants", "Professional organizations", "Taxpayers of professional accountants" and "State and tax administration". According to the findings obtained from the data obtained, most of the taxpayers who gave their opinions (except for the taxpayers who have a large-scale enterprise) stated that they did not fully meet the expectations of professional accountants. Therefore, the expectation of the taxpayer, who has a large-scale enterprise, and the quality of the service he received may differ at this point. There are differences of opinion from the paying taxpayers whether they meet the expectations of professional organizations. Some of the taxpayers stated that the chambers only collect dues and therefore do not benefit them, while others stated that the training provided by the professional institutions is sufficient and they are pleased with this situation. On the other hand, it is seen that 
it is in the form of evaluating the services provided by the tax authorities and the tax payment facilities provided by the state rather than the expectations of the taxpayers from the state and the tax administration.

As a result, it was determined from the findings that what expectations both accounting professionals and taxpayers have and what problems these expectations bring to the light at the same time. If these problems are resolved, tax revenues will increase, thus tax compliance will be ensured. 
Eskişehir Osmangazi Üniversitesi IïBF Dergisi 